\title{
Spatial and temporal scaling of periphyton growth on walls of estuarine mesocosms
}

\author{
Chung-Chi Chen*, John E. Petersen, W. Michael Kemp \\ University System of Maryland Center for Environmental Science, Horn Point Laboratory, PO Box 775, Cambridge, \\ Maryland 21613, USA
}

\begin{abstract}
Although expermental ecosystems are basic and versatile tools widely used in coastal research, periphytic growth on container walls is an intrinsic artifact that must be considered when interpreting results. To better understand how this artifact may confound extrapolation of results from controlled experiments to conditions in natural estuarine ecosystems, we examined how wall periphyton varled with container size and shape in summer and autumn experiments. Replicate $(\mathrm{n}=3)$ cylindrical mesocosms of 3 volumes $\left(0.1,1.0,10 \mathrm{~m}^{3}\right.$ ) were established in both constant-depth (depth $=1 \mathrm{~m}$ ) and constant-shape (radius/depth $=0.56$ ) series. Mesocosms were initiated with unfiltered estuarine water and homogenized sediments. Periphyton biomass and gross primary production (GPP) per unit of wall area increased with increasing radius $(I)$ or decreasing ratio of wall area $\left(A_{w}\right)$ to water volume $(V)$ for mesocosms in both series $\left(A_{w} / V=2 / r\right)$. As a consequence, periphyton bromass and metabolism expressed per unit of water volume increased as a quadratic function of increasing $A_{W} / V$ ratio. Results also suggest a secondary scaling effect, whereby wall periphyton growth may be directly related to mesocosm depth, although mechanisms for this effect remain unclear. Significant correlations between periphyton biomass (per $\mathrm{m}^{2}$ wall area) and 3 environmental factors (light attenuation coefficient, nutrient concentration, and zooplankton abundance) suggest that these factors may have played important roles in regulating wall growth. Additionally, effects of wall periphyton growth on plankton community dynamics were also indicated by the significant negative relations between periphyton biomass and measures of both phytoplankton and zooplankton abundance. The overall effect of periphyton on the experimental ecosystems was evident in the fact that periphyton accounted for over $50 \%$ of total ecosystem GPP and biomass after 2 to $4 \mathrm{wk}$ of these experiments. For mesocosm experiments designed to examine dynamics of planktonic-benthic ecosystems, our results imply that growth of wall periphyton, which is controlled by factors scaling to the radius of experimental ecosystems, tends to dominate major biotic pools and rates within weeks.
\end{abstract}

KEY WORDS: Dimension effects - Wall growth - Periphyton- Nutrients Zooplankton Light Phytoplankton Estuarine mesocosm

\section{INTRODUCTION}

Controlled experimental ecosystems have long been considered essential research tools for studies of community dynamics and ecological processes in aquatic environments (Odum 1984). These systems, often referred to as microcosms or mesocosms depending on their size, enable investigators to examine responses to perturbations from external or internal sources at the

\footnotetext{
·E-mall: chen@hpl.umces.edu
}

level of an integrated ecosystem (e.g. Kemp et al. 1980). In some cases, unconfined field experiments have been used as an alternative, in order to create semi-controlled studies in natural environments (e.g. Carpenter et al. 1995). Enclosed mesocosms, however, offer the only means for fully controlled experiments, from which causal relations can be inferred for whole ecosystems. Use of experimental ecosystems, particularly in lacustrine and estuarine research, has grown rapidly over the last 3 decades, and the many applications of mesocosms have been well documented le.g. Giesy 1980, Grice \& Reeve 1982, Gearing 1989, Lalli 
1990, Beyers \& Odum 1993). Mesocosms have been particularly valuable in studies of eutrophication and other perturbations in coastal marine ecosystems (e.g Kelly et al. 1985, Oviatt et al. 1995).

Despite the potential utility of mesocosms for addressing otherwise difficult questions in estuarine ecology, their use has been limited by several inherent shortcomings. There are, in fact, fundamental differences between these model ecosystems and their natural counterparts that limit the ability to extrapolate results from mesocosm to nature. Perhaps the 2 most important of these mesocosm artifacts are: (1) the reduced size, which limits their ability to support organisms at upper trophic levels (Dudzik et al. 1979, Gamble \& Davies 1982); and (2) the presence of walls (for control of material and energy exchange), which create artificial habitats for biotic growth (Eppley et al. 1978, Rees 1979). While the first of these artifacts (inability to sustain large predators in enclosed ecosystems) may limit mesocosm use for certain research, experimental systems have still been successfully employed for studies of trophic interactions involving fish (e.g. Threlkeld \& Drenner 1987, Kuuppo-Leinikki et al. 1994). Thus, the presence of walls and associated periphytic growth may be the most intrinsic and challenging of artifacts to be considered in the design of mesocosm studies (Jassby et al. 1977, Harte et al. 1980)

Several investigations have demonstrated a range of 'wall-effects' in experimental aquatic ecosystems. Wall periphyton can dominate total autotrophic biomass within several weeks (Rees 1979), and growth on container walls can significantly alter both ambient light fields and trophic interactions (Eppley et al. 1978). Wall communities can also modify nutrient uptake and regeneration processes in experimental ecosystems (Confer 1972, Eppley et al. 1978) and can dominate the partitioning and degradation of various contaminants (Kuiper 1981, Perez et al. 1991).

It has been suggested that the influence of wall periphyton on ecological processes in mesocosms is related to the ratio of wall area to water volume (Jassby et al. 1977, Dudzik et al. 1979, Gamble \& Davies 1982). This hypothesis derives from simple geometric considerations that assume that growth of wall periphyton, per wall area, is independent of enclosure dimensions and can be expressed as follows:

$$
B_{W} / A_{W}=C_{0}
$$

where $B_{w}$ is total biomass of wall periphyton, $A_{w}$ is the area of wall surface, and $C_{0}$ is a constant. Geometrically, biomass of wall periphyton can be expressed per unit of water volume $(V)$ simply by multiplying Eq. (1) by the ratio of wall area to water volume $\left(A_{W} / V\right)$ :

$$
B_{W} / V=C_{0}\left(A_{W} / V\right)
$$

For cylindrically shaped systems this can also be expressed in terms of mesocosm radius ( $r$ ):

$$
B_{W} / V=2 C_{0} I^{-1}
$$

This reasoning (Eqs. $2 \& 3$ ) indicates that effects of wall periphyton should be directly proportional to the ratio of wall area to tank volume and inversely related to system radius. Although these relations seem logical, they have never been tested directly, neither has the underlying assumption that periphyton growth per wall area is independent of system width (Eq. 1). Other system dimensions, such as water depth, may also regulate the growth of wall periphyton and associated ecological processes in mesocosm studies (Dudzik et al. 1979). Given the potential significance of wall growth in limiting extrapolation of results from experiments to predict behavior of natural estuarine ecosystems, it is surprising how few direct studies of the effects of wall periphyton have been reported.

Our study, which is part of a larger project to investigate scaling relations in experimental and natural ecosystems, was designed to investigate effects of wall periphyton in experimental estuarine ecosystems. We used experimental estuarine ecosystems of varying sizes and shapes, including: a 'constant-depth' series (depth $=1 \mathrm{~m}$ ) to evaluate the effects of radius alone; and a 'constant-shape' series (radius/depth $=0.56$ ) to examine the combined effects of radius and depth. We wished to (1) investigate how mesocosm dimensions (radius and depth) affect growth of wall periphyton; (2) understand other factors regulating periphyton growth; and (3) evaluate the effect of wall periphyton both on plankton community dynamics and on total autotrophic biomass and production.

\section{METHODS}

Experimental design. We considered mesocosm dimensions to be the experimental treatment. A total of 5 different dimensions of experimental ecosystems (designated as $A, B, C, D$, and $E$ in order of increasing diameter were used. They were organized into 2 groups referred to as constant-depth and constantshape series. Each series had 3 volumes $\left(0.1,1,10 \mathrm{~m}^{3}\right)$. The 2 series shared the same intermediate volume systems ( $\mathrm{C}$ tanks), and there were 3 replicates for all 5 system designs (a total of 15 tanks). The mesocosms designated $A, C$, and $E$ formed the constant-depth series, each having a water column depth of $1 \mathrm{~m}$. Volume in this series increased with increasing radius (Fig 1). The constant-shape series, which had a constant ratio of radius/depth of 0.56 , was formed by mesocosms designated B, C, and D. Volume in this series increased with increases in both radius and 
Experimental Ecosystem Design

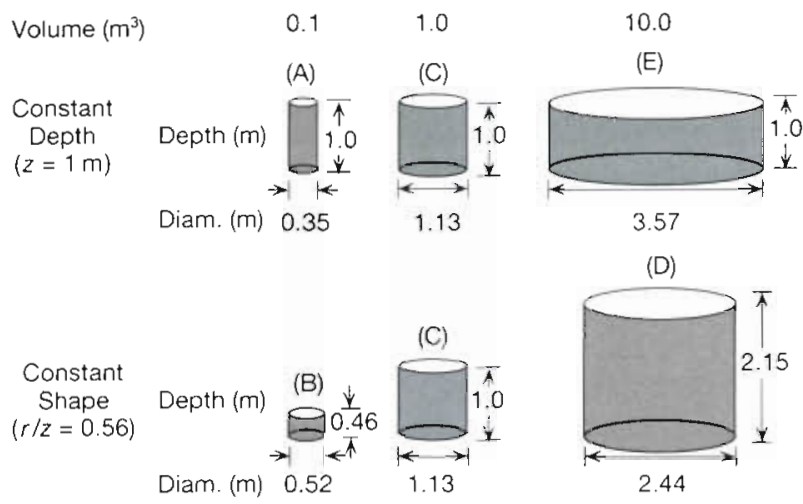

Fig. 1 Schematıc illustration of mesocosm dimensions and experimental design of this study. Mesocosms were designated as $A, B, C, D$, and $E$ in order of increasing diameter (Diam.). The mesocosms designated $A, C$, and $E$ form a constant-depth series, each having a water column depth $(z)$ of $1.0 \mathrm{~m}$. Mesocosms B, C and D form a constant-shape series, with a constant ratio of raduus/depth $(r / z)$ of 0.56 . Both constant-depth and constant-shape series share the intermediate $\mathrm{C}$ tanks

depth (Fig. 1). The $A_{W} / V$ ratio ranged from $1.12 \mathrm{~m}^{-1}$ in the wide $\mathrm{E}$ tanks to $11.25 \mathrm{~m}^{-1}$ in the narrow A tanks Experiments of $8 \mathrm{wk}$ duration were conducted in both summer (July 6 to August 25) and autumn (October 18 to December 2) 1994, allowing exploration of seasonal differences. Because growth of wall periphyton was a principal dependent variable, walls were not cleaned over the course of the experiments.

Experimental systems. Mesocosms were constructed of virtually opaque fiberglass-reinforced glazing material (Sun-Lite ${ }^{(B)}$ ) and were housed in a temperature-controlled room. Water temperatures nevertheless exhibited small diel variation (Table 1). Mesocosms were illuminated by banks of fluorescent and incandescent bulbs in a 12 h light: $12 \mathrm{~h}$ dark cycle. Mean surface light intensity was 268 (range, 230 to 325 ) $\mu \mathrm{E} \mathrm{m}^{-2} \mathrm{~s}^{-1}$ (Table 1). Mixing was accomplished by means of large, slow-moving PVC paddles that produced relatively uniform turbulence typical of estuarine surface waters and vertical mixing times ranging from 4 to $39 \mathrm{~min}$ (Table 1). All mesocosms were initiated with sediments composed of a mixture of sand and natural muds, and unfiltered mesohaline water (salinity, 8 to 12 psu) from the Choptank River estuary, a tributary of Chesapeake Bay, USA. Ten percent of the volume of each mesocosm was drained daily and replaced with filtered $(0.5 \mu \mathrm{m})$ estuarine water. Because nutrient concentrations were low in both experimental seasons, a nutrient pulse was administered to enhance treatment effects in each experiment. Nutrient additions were started on Days 34 and 21 in summer and autumn experiments, respectively. In both cases 3 pulses of nutrients were added at $12 \mathrm{~h}$ intervals to bring the concentration of ammonium $\left(\mathrm{NH}_{4}{ }^{+}\right)$up to $50 \mu \mathrm{M}$, with phosphate $\left(\mathrm{PO}_{4}{ }^{3-}\right)$ and dissolved silica (dSi) pulsed simultaneously to achieve levels of $3.1 \mu \mathrm{M}$ and $50 \mu \mathrm{M}$, respectively.

Sampling and analysis. The key properties and processes measured in this study include: light intensity; biomass, and production of wall periphyton and phytoplankton; nutrient concentration; zooplankton abundance; and total system metabolism. The vertical distribution of photosynthetically active radiation (PAR) was measured twice weekly using hemispherical sensors (Li Cor, $2 \pi$ ). A coefficient for attenuation of diffuse downwelling PAR, $k_{d}$, was calculated as the slope of the exponential regression of PAR versus depth. In addition to attenuation by dissolved and particulate materials in the water column (as well as water itself), $k_{d}$ was also affected by light absorption by mesocosm walls (Kemp unpubl. data)

Water quality was monitored by sampling nutrients $\left(\mathrm{NH}_{4}{ }^{+}, \mathrm{NO}_{2}{ }^{-}+\mathrm{NO}_{3}{ }^{-}, \mathrm{PO}_{4}{ }^{3-}\right.$, and $\left.\mathrm{dSi}\right)$ and water column chlorophyll a (chl a) twice weekly. Standard automated wet chemical methods were used to measure nutrient concentrations (Technicon AAII autoanalyzer) following filtration (Parsons et al. 1984). In vivo water column chl a concentrations were determined fluorometerically (WET Labs model 9602004), with data

Table 1. Some physical variables of the experimental ecosystems. Mixing time: average time required for a water parcel to move through the full vertical dimension (from top to bottom) of the mesocosm water columns. PAR: mean photosynthetically active radiation at water surface for summer and autumn experiments. Temp: mean water temperatures for summer and autumn experiments

\begin{tabular}{|c|c|c|c|c|c|c|}
\hline \multicolumn{2}{|l|}{$\begin{array}{l}\text { Physical variable } \\
\text { (abbreviations, units) }\end{array}$} & \multicolumn{5}{|c|}{ Mesocosm type } \\
\hline \multicolumn{2}{|c|}{ Ratio of wall area/water volume $\left(A_{W} / V, \mathrm{~m}^{-1}\right)$} & 11.25 & 7.68 & 3.54 & 1.64 & 1.12 \\
\hline \multicolumn{2}{|l|}{ Mixing time (min) } & 14 & 4 & 12 & 39 & 15 \\
\hline $\mathrm{PAR} \pm \mathrm{SE}\left(\mu \mathrm{E} \mathrm{m}^{-2} \mathrm{~s}^{-1}\right)$ & $\begin{array}{l}\text { Summer } \\
\text { Autumn }\end{array}$ & $\begin{array}{l}246 \pm 10 \\
230 \pm 7\end{array}$ & $\begin{array}{l}246 \pm 8 \\
246 \pm 15\end{array}$ & $\begin{array}{l}325 \pm 17 \\
313 \pm 15\end{array}$ & $\begin{array}{l}275 \pm 11 \\
269 \pm 4\end{array}$ & $\begin{array}{l}262 \pm 8 \\
268 \pm 7\end{array}$ \\
\hline Temp $\pm 1 / 2$ diel range $\left({ }^{\circ} \mathrm{C}\right)$ & $\begin{array}{l}\text { Summer } \\
\text { Autumn }\end{array}$ & $\begin{array}{l}21.9 \pm 2.6 \\
21.6 \pm 1.4\end{array}$ & $\begin{array}{l}23.8 \pm 3.2 \\
23.0 \pm 2.5\end{array}$ & $\begin{array}{l}23.8 \pm 1.3 \\
23.2 \pm 1.0\end{array}$ & $\begin{array}{l}24.0 \pm 0.5 \\
22.6 \pm 0.5\end{array}$ & $\begin{array}{l}22.7 \pm 0.9 \\
21.6 \pm 0.8\end{array}$ \\
\hline
\end{tabular}


calibrated both by in vitro fluorometry (Turner Designs model 10 series) following extraction with $90 \%$ acetone and by high performance liquid chromatography (Van Heukelem et al. 1994).

Zooplankton were collected twice weekly using a diaphragm pump and filtered through a $64 \mu \mathrm{m}$ mesh at a rate of $201 \mathrm{~min}^{-1}$ Abundance and size distribution of zooplankton (primarily copepods) were determined with an Optical Plankton Counter (OPC-Focal Technologies) which was calibrated against microscopic enumeration of samples (M. Roman \& A. Gauzens unpubl. data) The minimum sensitivity of the OPC was $200 \mu m$ equivalent spherical diameter.

Total primary production and respiration of the experimental ecosystems were measured by tracing dawn-dusk-dawn (e.g Odum 1956) changes in dissolved oxygen $\left(\mathrm{O}_{2}\right)$ using polargraphic electrodes (Orbisphere model 2607) calibrated twice daily with standard Winkler titration techniques (Carritt \& Carpenter 1966). Net primary production (NPP), which was taken as the net $\mathrm{O}_{2}$ production during the light period, was calculated as the difference between measured $\mathrm{O}_{2}$ concentration at dawn and at dusk of the same day divided by daylength. The difference in $\mathrm{O}_{2}$ between dusk and the following dawn was used to compute nighttime respiration $(R)$. Gross primary production (GPP) was defined operationally as the sum of $R$ (taken as a positive number) and NPP (Odum 1956, Oviatt et al. 1995). These metabolic rates were adjusted for air-water gas exchange with diffusion constants derived from previous experiments (Petersen et al. 1997)

To monitor periphyton. growth on walls of mesocosms, we deployed and retrieved fjberglass strips fabricated from the wall material. Replicate fiberglass strips (width of $1.6 \mathrm{~cm}$, extending the full depth of the mesocosms) were attached to the wall surface with tape (3M model 4016) at the beginning of each experiment. These were removed periodically and used to estimate biomass (chl a), nutrient status (CHN analysis), and community metabolism of wall periphyton in chamber incubations.

Vertical profiles of chl a were obtained weekly by scraping material from the strips at 20 to $35 \mathrm{~cm}$ depth intervals, depending on the size of mesocosm. Scraped material was extracted in $90 \%$ acetone and sonicated to aid pigment extraction (Whitney \& Darley 1979). After centrifugation, chl a in the extracted samples was measured fluorometerically (Turner Designs). The chl a concentration of scraped material was used as an index of periphytic algal biomass. Total biomass on mesocosm walls was estimated by multiplying values from strips by the area of walls. Samples for CHN analysis were pooled from whole strips and were analyzed to indicate relative nitrogen assimilation using standard methods (CE 440 Analyzer)
Production and respiration rates for plankton and periphyton communities were determined at approximately weekly intervals by measuring dawn-duskdawn changes in $\mathrm{O}_{2}$ over $24 \mathrm{~h}$ periods in incubation chambers. Chambers were constructed of clear acrylic tubes with a diameter of $7 \mathrm{~cm}$ and extended the whole depth of each mesocosm. The top and bottom of each chamber were sealed with transparent acrylic caps to exclude sediments and eliminate gas exchange with the atmosphere. To prevent stratification, magnetic stir bars were housed in cages at mid-depth of each chamber. Bars were turned by means of a magnetic stirring motor attached to the side of the chambers so as to minimize obstruction of downwelling light. In each mesocosm 2 chambers were incubated concurrently, one with water from the mesocosm and the other with both water and a strip of wall material. Values of NPP, $R$, and GPP of plankton communities were estimated (as described above for whole ecosystem) from the chambers with water only. These values were subtracted from those measured in the incubation chambers that contained strips of wall material in order to estimate metabolic rates of the periphyton communities.

Statistical analysis. Statistical analyses were performed using SYSTAT (1992) software for Macintosh computers. Repeated-measures analysis (Crowder \& Hand 1990) was used to assess differences (among mesocosms of different sizes and shapes) in periphytic biomass and GPP, as well as the relative contribution of periphyton to total ecosystem biomass and GPP in constant-depth and constant-shape series. Samples from different dates were assessed as repeated measurement for each treatment, and p-values were calculated for testing effects of both treatment $\left(p_{1}\right)$ and time $x$ treatment $\left(\mathrm{p}_{2}\right)$.

Regression analyses were used to explore relations among variables. To examine scaling effects on growth of wall periphyton, mean periphyton biomass and GPP (per $\mathrm{m}^{2}$ wall area) of the 5 different-dimensioned mesocosms were pooled and regressed against the $A_{w} / V$ ratio using linear regression analyses. Linear regression analyses were also performed between $A_{u} / V$ ratio and mean periphytic biomass for both preand post-nutrient-addition periods in both seasons. To explore the role of mesocosm depth in regulating periphytic growth, a 2 -variable ( $A_{w} / V$ ratio and depth) multiple linear regression analysis was performed against mean periphyton biomass and GPP (per $\mathrm{m}^{2}$ wall area). Linear regression analyses were also applied to examine relationships: (1) periphyton community NPP versus $R$, to assess the relative balance between production and consumption of organic matter within periphytic communities; and (2) mean periphyton biomass $\left(\mathrm{m}^{-2}\right.$ and $\left.\mathrm{m}^{-3}\right)$ versus mean values 
for environmental conditions ( $k_{d}$, nutrient concentration, zooplankton abundance), to understand how growth of periphyton was related to these factors.

Analyses of covariance (ANCOVA.) were used to examine the relationships between phytoplankton $\left(\mathrm{m}^{-3}\right)$ versus periphyton $\left(\mathrm{m}^{-2}\right)$ characteristics (biomass and production). Analysis were conducted during both pre-and post-nutrient-addition periods in each dimension of mesocosm. An ANCOVA model of 'phytoplankton $=\alpha \cdot \operatorname{Cosm}_{i}+\beta \cdot(\text { periphyton })^{\prime}$ ' was used, where Cosm, is a replicate mesocosm and $\alpha$ and $\beta$ are coefficients of the model. For biomass analysis, weekly average phytoplankton biomass and corresponding periphyton biomass were used. The ' $\beta$ ' coefficients for both biomass and GPP analysis in pre-nutrient-addition periods were pooled and further regressed linearly against mesocosm $A_{\mathrm{W}} / V$ ratio to examine scaling effects on intensity of phytoplankton-periphyton interaction. Statistical tests of linear and multiple linear correlations were performed using analyses of variance (ANOVA). Mean values of $k_{d}$, nutrient (i.e. DIN, $\mathrm{PO}_{4}{ }^{3-}$, dSi) concentration, periphyton biomass $\left(\mathrm{m}^{-2}\right.$ and $\left.\mathrm{m}^{-3}\right)$ and zooplankton abundance (200 to $1400 \mu \mathrm{m}$ size fraction) were calculated as averages over the course of experiments for each mesocosm type (A, B, C, D, and E).

\section{RESULTS}

\section{Biomass and GPP of wall periphyton}

The general temporal patterns of periphyton accumulation were similar in all mesocosms and in both seasons. Wall periphyton biomass ( $\mathrm{mg}$ chl a $\mathrm{m}^{-2}$ ) increased exponentially at the beginning of summer and autumn experiments (Fig. 2). Biomass peaked 4 to 6 wh after experiments began, with maximum values occurring 1 to 2 wk after the nutrient addition, and then declined as material sloughed off the walls of the tanks. Vertical profiles of wall periphyton biomass revealed that maximum values occurred near middepth of most tanks, with biomass there averaging almost $25 \%$ higher than that near the water surface. However, these vertical differences in distribution were not statistically significant. Periphyton biomass was an order of magnitude higher in the summer experiment compared to the autumn (Fig. 2).

In the constant-depth series, significant treatment effects on periphyton biomass $\left(\mathrm{m}^{-2}\right)$ were detected among tanks in both summer $\left(\mathrm{p}_{1}=0.04\right.$ for treatment effects; $p_{2}=0.18$ for treatment $\times$ time effects) and autumn $\left(\mathrm{p}_{1}=0.03_{i} \mathrm{p}_{2}<0.01\right)$ experiments. Periphyton biomass per $\mathrm{m}^{2}$ wall area was positively related to the radius of tanks, with lowest values occurring in the narrow $A$ tanks, intermediate values in the $C$ tanks,

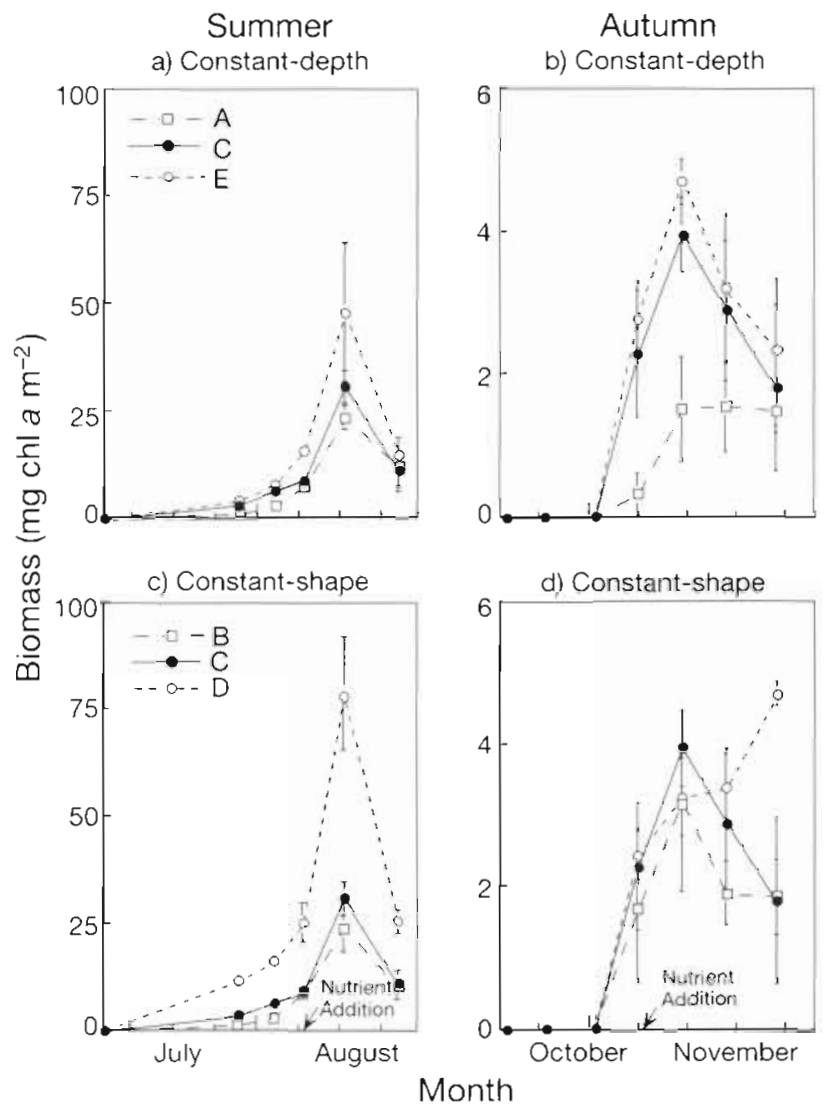

Fig. 2. Time course of periphytic biomass on mesocosm walls in constant-depth and constant-shape series in summer and autumn experiments. Labels shown in a and $c$ also apply to $b$

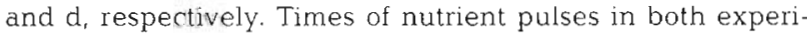
ments are indicated in $c$ and $d$. Values are mean $\pm S E, n=3$ replicated mesocosms. Note scale change on $y$-axis between summer and autumn experiments

and highest values in the wide $E$ tanks (Fig. 2a, b). These differences in periphyton biomass between tanks were substantially amplified after nutrient addition.

Significant differences in periphyton biomass per $\mathrm{m}^{2}$ wall area were also evident among different size tanks in the constant-shape series in summer ( $\mathrm{p}_{1}$ and $\mathrm{p}_{2}<$ 0.01 ). Biomass was lowest in the $B$ tanks which have the smallest radius in this series (Fig. 1), intermediate in the $\mathrm{C}$ tanks, and highest in the $\mathrm{D}$ tanks in the summer experiment (Fig. 2c) This trend was not apparent in the autumn, where the treatment effect was not significant (Fig. 2d; $\mathrm{p}_{1}=0.16 ; \mathrm{p}_{2}<0.01$ ).

We examined the relative balance between production and consumption of organic matter within the periphytic communities by examining the relationship between NPP and $R$. NPP and $R$ of the periphyton communities were significantly correlated in both seasons, with $r^{2}$ values of 0.52 and 0.70 for summer and autumn, 


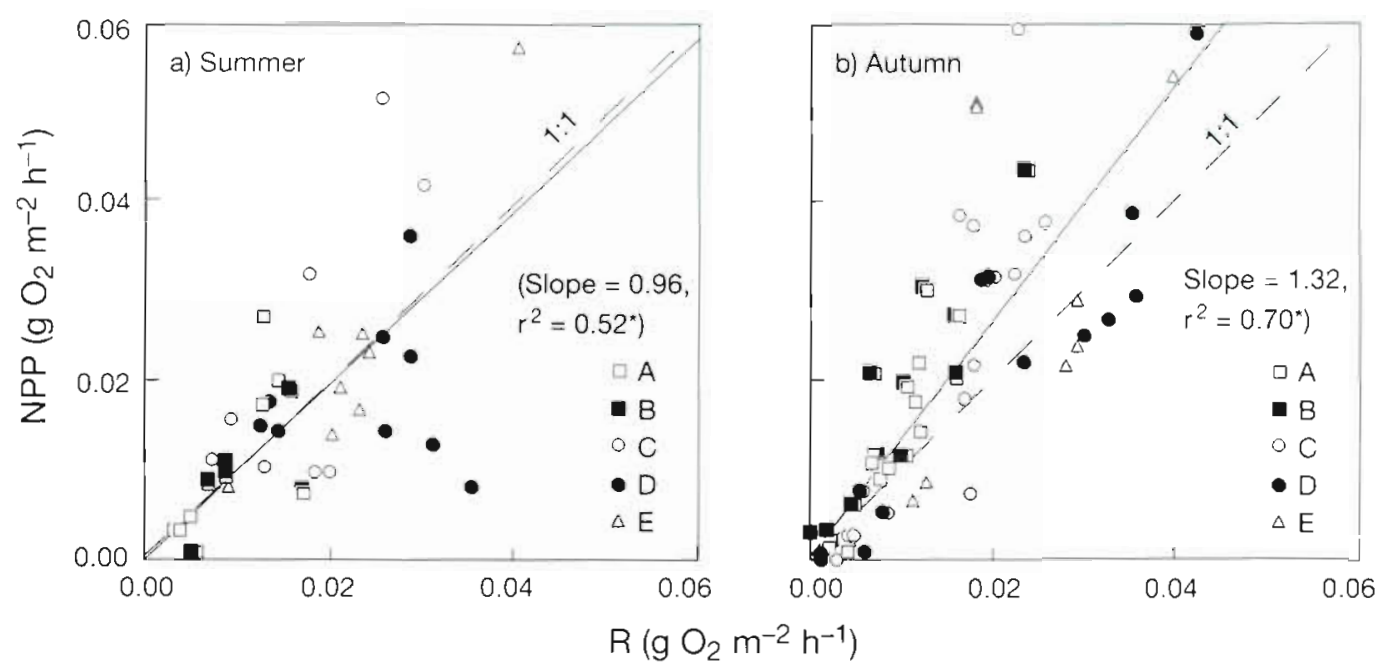

Fig. 3. Correlations between daytime net primary production (NPP) and night respiration $(R)$ of periphyton communities on mesocosm walls in summer $(n=45)$ and autumn $(n=75)$ experiments. Significant at $p<0.01$

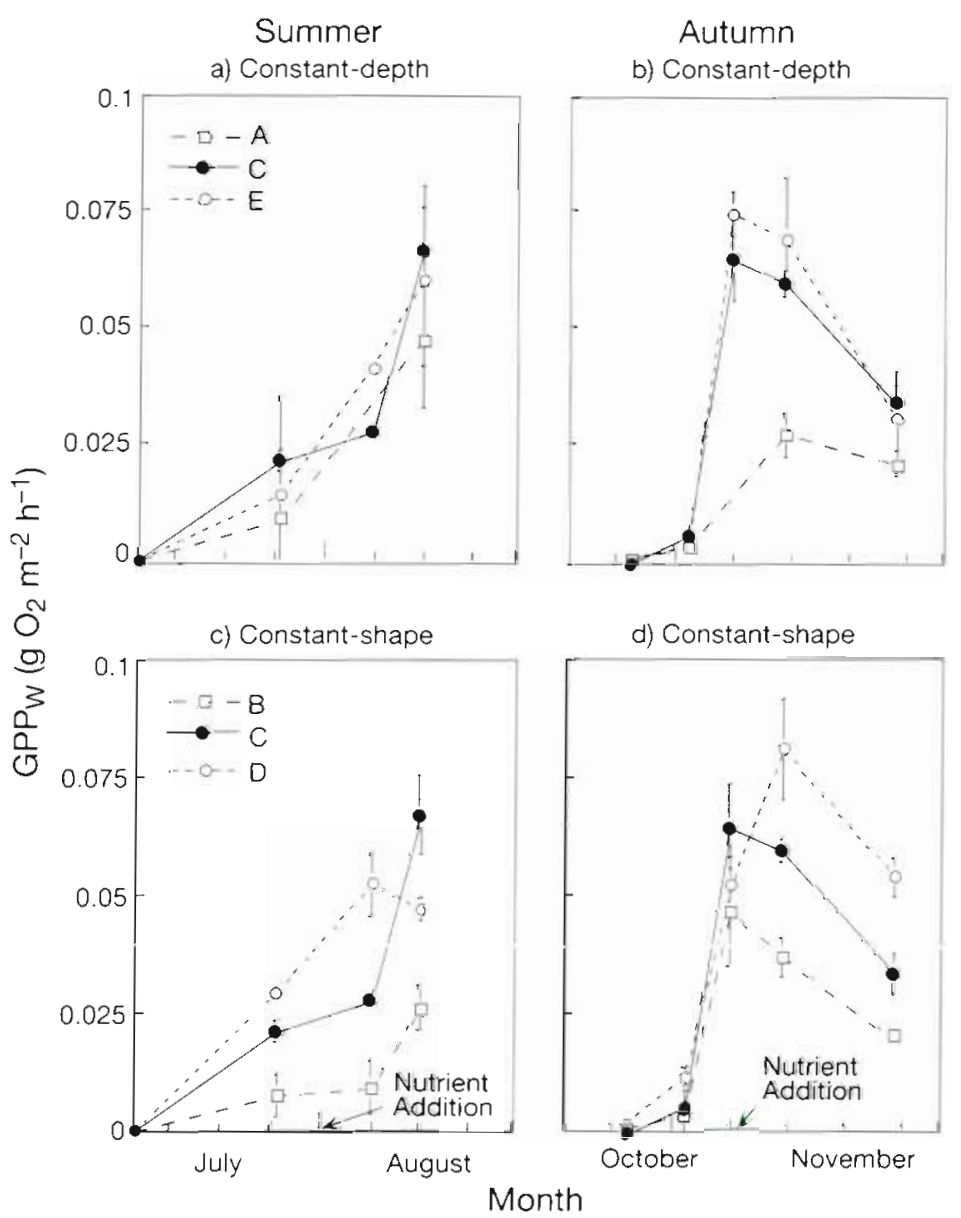

Fig 4. Gross primary production (GPP) of periphyton community on mesocosm walls in constant-depth and constant-shape series for summer and autumn experiments. Labels shown in a and $c$ also apply to $b$ and $d$, respectively. Times of nutrient pulses in both experiments are indicated in $c$ and $d$ respectively (Fig. 3). Although ratios of $N P P / R$ appear to have been higher for the smallest mesocosms (A and B tanks), differences among systems were not significant. At higher rates of primary production $(>0.02 \mathrm{~g}$ $\mathrm{O}_{2} \mathrm{~m}^{-2} \mathrm{~h}^{-1}$ ), periphytic communities tended to be more autotrophic $(\mathrm{NPP}>R$ ). This autotrophic metabolism is reflected in the net accumulation of periphyton biomass during Weeks 3 to 6 in all mesocosms and both seasons. No significant differences were found in the relationship between NPP and $R$ among mesocosms of different dimensions. The parallel variations in NPP and $R$ apparent here (Fig. 3) suggest that GPP provides a more sensitive integrated measure of metabolic activity. Therefore, we used GPP instead of NPP or $R$ as the principal measure of experimental ecosystem metabolism.

As with biomass, rates of GPP per $\mathrm{m}^{2}$ wall area of the periphytic communities in all mesocosms and in both seasons were initially low, peaked after the nutrient addition, and then declined toward the end of the experiment (Fig. 4). In the constant-depth series, differences in periphyton GPP among tanks were not significant in either summer or autumn experiments. However, in the autumn experiment, by the second week after nutrient pulse addition there was a clear pattern of increasing GPP with increasing radius (Fig $4 \mathrm{~b}$ ). The lack of a statistically detectable difference is probably due to loss of data for A tanks on the third sampling date. In the constant-shape series, significant 
differences in periphyton GPP among these tanks were evident in both summer $\left(p_{1}\right.$ and $\left.p_{2} \leq 0.01\right)$ and autumn $\left(p_{1}\right.$ and $p_{2} \leq 0.01$ ) experiments (Fig. 4c, d). Periphyton GPP was lowest in the $B$ tanks, intermediate in the $C$ tanks, and highest in the D tanks

\section{Scaling effects on growth of wall periphyton}

To test the hypothesis that periphyton wall growth tends to be proportional to the mesocosm $A_{W} / V$ ratio, we regressed measures of mean periphytic biomass (expressed both per $\mathrm{m}^{2}$ wall area and per $\mathrm{m}^{3}$ water volume) against this ratio (Fig. 5). Scaling effects on growth of wall periphyton were examined by testing the significance of the slope of the relationship between periphytic biomass $\left(\mathrm{m}^{-2}\right)$ and $A_{W} / V$ ratio. Here, data for all 5 mesocosm types were combined rather than separated into the 2 series. For both experiments, significant negatively linear relationships were found
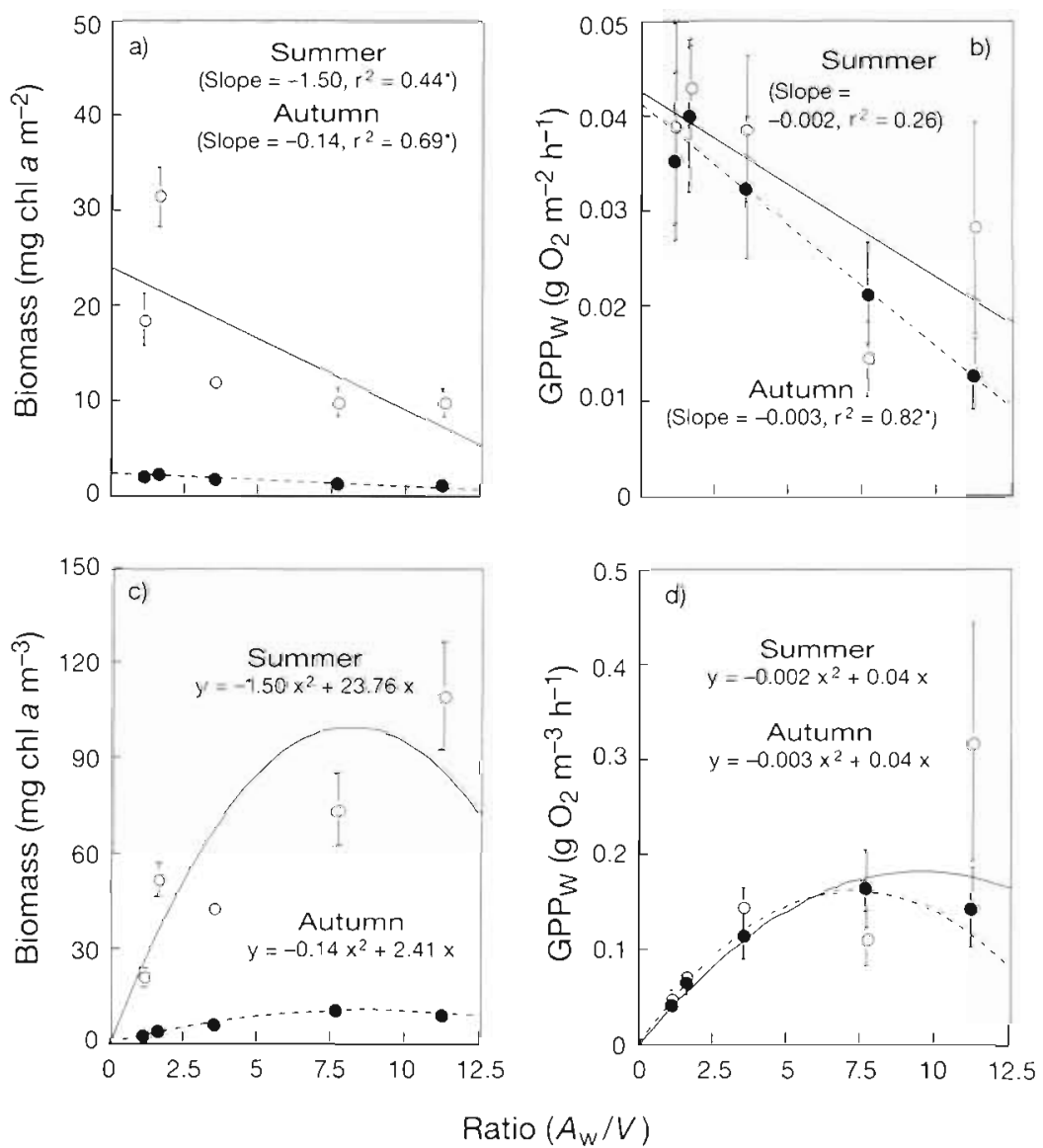

Fig. 5. Scaling relationships between ratio of wall area to water volume $\left(A_{W} / V\right)$ vs mean periphyton chl a and mean gross primary production (GPP), both expressed per $\mathrm{m}^{2}$ wall area $(a, b)$ and per $\mathrm{m}^{3}$ water volume $(c, d)$, for summer $(0$, solid lines) and autumn (• dashed lines) experiments. "Significant at $p \leq 0.01$ between mean periphyton biomass $\left(\mathrm{m}^{-2}\right)$ and the $A_{W} / V$ ratio, with slopes of -1.50 and -0.14 in summer $(p \leq$ 0.01 ) and autumn ( $\leq 0.01)$ experiments, respectively (Fig. 5a). Thus, growth of wall periphyton (per $\mathrm{m}^{2}$ wall area) was inversely related to the $A_{w} / V$ ratio and directly proportional to system radius. Similar trends were also found in mean periphyton biomass of preand post-nutrient-addition periods in both seasons (all $p<0.05$ ). Significant negative linear relationships were also evident for periphyton GPP $\left(\mathrm{g} \mathrm{O}_{2} \mathrm{~m}^{-2} \mathrm{~h}^{-1}\right)$ versus $A_{W} / V$ ratio $\left(\mathrm{r}^{2}=0.82, \mathrm{p} \leq 0.01\right)$ for the autumn experiment; there was no significant relation in the summer (Fig. 5b). There was a general trend in that the deeper tanks of a given volume ( $D$ tanks vs $E$ tanks, A tanks vs B tanks) had higher biomass and GPP. Significant quadratic relationships were observed between average volumetric biomass of the periphytic community and $A_{W} / V$ ratio in both summer and autumn experiments (Fig. 5c). Similar significant quadratic relationships were also evident between mean periphyton GPP ( $\left.\mathrm{g} \mathrm{O}_{2} \mathrm{~m}^{-3} \mathrm{~h}^{-1}\right)$ and the $A_{W} / V$ ratio in both seasons (Fig. $5 \mathrm{~d}$ ).

To explore potential effects of water column depth in regulating growth of wall periphyton, we performed 2-variable (e.g. $A_{W} / V$ and depth) multiple linear regression analyses. Similar results as those obtained from linear regression analysis were evident on variable 'Aw/V ratio' effects on periphyton. Water depth also had significant effects on periphyton biomass in the summer experiment $(\mathrm{p}<0.01)$.

\section{Relations with light, nutrients and zooplankton}

Correlation between mean periphytic biomass (per $\mathrm{m}^{2}$ wall area) and mean light attenuation coefficients $\left(k_{d}\right)$, mean nutrient concentration (e.g. DIN, $\mathrm{PO}_{4}{ }^{3-}, \mathrm{dSi}$ ), and mean zooplankton abundance were used to explore how growth of wall periphyton might be modulated by these abiotic and biotic factors (Table 2). Significant linear correlations were found between periphytic biomass $\left(\mathrm{m}^{-2}\right)$ and values of $k_{d}$ measured in experimental water column for both seasons. Periphytic biomass $\left(\mathrm{m}^{-2}\right)$ increased linearly with decreasing $k_{d}$, with $r^{2}$ values 0.44 and 0.72 in sum- 
Table 2. Linear regression between mean wall periphyton biomass (mg $c h l a)$, both per $m^{2}$ of wall area and per $m^{3}$ of water volume, and mean light attenuation coefficient $\left(k_{d}\right)$; mean nutrient concentrations of dissolved inorganic nitrogen (DIN), dissolved phosphate $\left(\mathrm{PO}_{4}{ }^{-1}\right)$ and dissolved silica (dSi); and mean zooplankton abundance $\left(10^{b}\right.$ ind $\left.\mathrm{m}^{-3}\right)$ over the course of summer and autumn experiments. 'Significant at $p \leq 0.05$

\begin{tabular}{|c|c|c|c|c|c|}
\hline \multirow[t]{2}{*}{ Variable } & \multirow[t]{2}{*}{ Period } & \multicolumn{2}{|c|}{ Wall periphyton $\left(\mathrm{m}^{-2}\right)$} & \multicolumn{2}{|c|}{ Wall periphyton $\left(\mathrm{m}^{-3} \mathrm{f}\right.$} \\
\hline & & & & & \\
\hline \multirow[t]{2}{*}{$k_{d}\left(\mathrm{~m}^{-1}\right)$} & Summer & -0.03 & $0.44^{\circ}$ & 0.01 & $0.78^{\circ}$ \\
\hline & Autumn & -0.45 & $0.72^{\circ}$ & 0.06 & $0.46^{\circ}$ \\
\hline \multirow[t]{2}{*}{$\operatorname{DIN}(\mu \mathrm{M})$} & Summer & 0.43 & $0.79^{\circ}$ & -0.04 & 0.09 \\
\hline & Autumn & 1.04 & 0.08 & -0.38 & $0.37^{\circ}$ \\
\hline \multirow[t]{2}{*}{$\mathrm{PO}_{4}{ }^{3-}(\mu \mathrm{M})$} & Summer & 0.03 & $0.88^{\circ}$ & -0.00 & 0.17 \\
\hline & Autumn & 0.21 & $0.60^{\circ}$ & -0.03 & $0.46^{\circ}$ \\
\hline \multirow{2}{*}{$\mathrm{dSi}(\mu \mathrm{M})$} & Summer & 1.34 & $0.72^{\circ}$ & -0.27 & $0.40^{\circ}$ \\
\hline & Altumn & 5.70 & $0.64^{\circ}$ & -0.75 & $0.40^{\circ}$ \\
\hline \multirow[t]{2}{*}{ Zooplankton } & Summer & -463 & 0.25 & 146 & $0.35^{\circ}$ \\
\hline & Autumn & -12505 & $0.33^{\circ}$ & 3080 & $0.72^{\circ}$ \\
\hline
\end{tabular}

after nutrient addition. In most cases phytoplankton also had a secondary maximum occurring at $1 \mathrm{wk}$ after the nutrient pulse. To quantify this pattern, we pooled contemporaneous data on biomass and GPP of phytoplankton $\left(\mathrm{m}^{-3}\right)$ and periphyton $\left(\mathrm{m}^{-2}\right)$ from each mesocosm type and separated data by season into pre- and post-nutrient-addition periods. Before the nutrient addition treatment, significant negative correlations were evident between biomass of periphyton ( $\mathrm{mg} \mathrm{chl} \mathrm{a} \mathrm{m}^{-2}$ ) and phytoplankton ( $\mathrm{mg} \mathrm{chl} \mathrm{a} \mathrm{m}^{-3}$ ) for most tanks in both seasons (Table 3). Following nutrient treatments in autumn, however, most relations became non-significant, with both positive and negative slopes. Limited data for the post-nutrient period in the summer precluded similar analyses. Although negative slopes were also found in most cases for correlations between GPP

mer and autumn experiments, respectively (Table 2). Significant positive relations were also found between periphytic biomass $\left(\mathrm{m}^{-2}\right)$ and nutrient (DIN, $\mathrm{PO}_{4}{ }^{3-}, \mathrm{dSi}$ ) concentrations in both experiments (except DIN in autumn, Table 2). A significant negative correlation was evident between periphytic biomass $\left(\mathrm{m}^{-2}\right)$ and zooplankton abundance in autumn experiments; however, this correlation was not significant in the summer (Table 2).

In contrast, slopes of linear relationships between periphyton volumetric biomass $\left(\mathrm{m}^{-3}\right)$ and these environmental variables were opposite to those observed for periphytic biomass expressed per $\mathrm{m}^{2}$ wall area (Table 2). Significant positive correlations were found between periphytic biomass $\left(\mathrm{m}^{-3}\right)$ and $k_{d}$, with $\mathrm{r}^{2}$ values of 0.78 and 0.46 in summer and autumn, respectively (Table 2). The inverse relationships were evident between nutrient (DIN, $\mathrm{PO}_{4}{ }^{3-}$, dSi) concentrations and periphyton biomass $\left(\mathrm{m}^{-3}\right)$ in most analyses, except for DIN and $\mathrm{PO}_{4}^{3-}$ in summer experiments (Table 2). Significant positive relationships were evident between periphytic volumetric biomass and zooplankton abundance, with $r^{2}$ values of 0.35 and 0.72 in summer and autumn experiments, respectively (Table 2 ).

\section{Relations between wall periphyton and phytoplankton}

Temporal patterns of phytoplankton and periphyton biomass exhibited a distinct asynchrony for all mesocosms and both seasons. Phytoplankton displayed a peak at 1 to $2 \mathrm{wk}$ after initiation of each experiment (C. Madden \& T. Malone unpubl. data), while periphyton abundance continued to increase until 1 to $2 \mathrm{wk}$ of periphyton $\left(\mathrm{m}^{-2}\right)$ and phytoplankton $\left(\mathrm{m}^{-3}\right)$, few of these relations were significant (Table 3 ).

To explore potential scaling effects on the interaction between periphyton and phytoplankton, we pooled the coefficients for both biomass and GPP (i.e. same coefficients as shown in Table 3 ) in pre-nutrient-addition periods and regressed them against mesocosm $A_{w} / V$ ratios. These relationships all displayed strong trends $\left(r^{2} \geq 0.70\right)$ of decreasing slope (increasingly negative) with increasing $A_{W} / V$ for both variables and seasons (Fig 6). However, only the correlations for biomass coefficients versus $A_{W} / V$ ratio in summer $\left(r^{2}=0.80\right)$ and for GPP coefficients versus $A_{w} / V$ ratio in autumn $\left(\mathrm{r}^{2}=0.80\right)$ were significant. Thus, the strength of the interactions between periphyton and phytoplankton biomass and GPP increased directly with $A_{w} / V$ ratio.

\section{Contribution of wall periphyton to experimental ecosystems}

The relative contributions of periphyton to total biomass and metabolic activity of experimental ecosystems were assessed using 2 ratios, GPPW/GPPT and $\mathrm{chl}_{W} /$ $\mathrm{chl}_{T}$. Here, GPP $\mathrm{W}$ and GPP indicate GPP $\left(\mathrm{g} \mathrm{O}_{2} \mathrm{~m}^{-3}\right.$ $\mathrm{h}^{-1}$ ) of the wall and total ecosystem, respectively. $\mathrm{Chl}_{\mathrm{W}}$ and $\mathrm{chl}_{\mathrm{T}}$ are chl a (per $\mathrm{m}^{3}$ water volume) contributions of periphyton alone and the combined periphyton plus phytoplankton biomass, respectively. It is important to note that sediment autotrophic biomass was not measured and is therefore excluded from our analysis of chlorophyll ratios. In similar experiments conducted in our systems, sediment microalgae has accounted for over $30 \%$ of total autotrophic biomass. 
Table 3. Analysis of covariance (ANCOVA) between biomass of phytoplankton

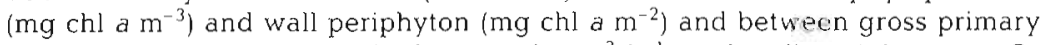
production (GPP) of phytoplankton $\left(\mathrm{g} \mathrm{O}_{2} \mathrm{~m}^{-3} \mathrm{~h}^{-1}\right)$ and wall periphyton $\left(\mathrm{g} \mathrm{O}_{2}\right.$ $\mathrm{m}^{-2} \mathrm{~h}^{-1}$ ) in different experimental tanks (A, B, C, D, and $E$ ) in pre- and postnutrient-addition periods in summer and autumn experiments. The coefficients (coeff.) of wall periphyton characteristic and $r^{2}$ of ANCOVA are shown. For biomass analyses in summer and autumn experiments, $n=12$ and 9, respectively, and $n=6$ for all GPP analyses in both experiments. nd: no data available

- Significant at $p<0.05$

\begin{tabular}{|c|c|c|c|c|c|c|c|c|}
\hline \multirow[t]{3}{*}{ Tank } & \multicolumn{4}{|c|}{ Summer } & \multicolumn{4}{|c|}{ Autumn } \\
\hline & \multicolumn{2}{|c|}{ Chlorophyll } & \multicolumn{2}{|c|}{ GPP } & \multicolumn{2}{|c|}{ Chlorophyll } & \multicolumn{2}{|c|}{ GPP } \\
\hline & Coeff. & $r^{2}$ & Coeff. & $\mathrm{r}^{2}$ & Coeff & $r^{2}$ & Coeff & $r^{2}$ \\
\hline \multicolumn{9}{|c|}{ Pre-nutrient-addition } \\
\hline A & -0.89 & $0.41^{\circ}$ & nd & nd & -11.00 & 0.50 & -15.85 & 0.70 \\
\hline B & -0.53 & 0.28 & -16.09 & $0.99^{\circ}$ & -3.30 & $0.59^{\circ}$ & -3.85 & 0.29 \\
\hline $\mathrm{C}$ & -0.61 & $0.54^{\circ}$ & -0.29 & 0.62 & -1.94 & 0.45 & -4.89 & 0.55 \\
\hline $\mathrm{D}$ & -0.26 & $0.75^{\circ}$ & -2.08 & 0.80 & -3.31 & $0.95^{\circ}$ & 0.92 & 0.75 \\
\hline E & -0.19 & $0.50^{\circ}$ & -1.25 & 0.90 & -1.97 & $0.85^{\circ}$ & 8.16 & 0.51 \\
\hline \multicolumn{9}{|c|}{ Post-nutrient-addition } \\
\hline A & nd & & nd & & -8.37 & 0.26 & -12.73 & $0.98^{\circ}-\cos { }^{\circ}$ \\
\hline B & nd & & nd & & 3.09 & $0.85^{\circ}$ & -4.38 & $0.77^{\circ}$ \\
\hline $\mathrm{C}$ & nd & & nd & & 1.28 & 0.42 & -1.71 & 0.56 \\
\hline D & nd & & nd & & -1.58 & 0.27 & -3.00 & 0.77 \\
\hline E & nd & & nd & & 1.79 & $0.80^{\circ}$ & -0.98 & 0.57 \\
\hline
\end{tabular}

The $\mathrm{chl}_{W} / \mathrm{chl}_{T}$ ratio in the constantshape series also decreased significantly ( $p_{1}$ and $p_{2} \leq 0.05$ ) with increasing radius or decreasing $A_{W} / V$ ratio in the autumn (Fig. $7 \mathrm{~d}$ ), but not in the summer (Fig. 7c).

As with biomass, periphyton GPP accounted for over $50 \%$ of total system GPP 3 wk into the experiments in both seasons for many of the mesocosms (Fig. 8). Periphytic production developed more slowly in the B and E tanks. Comparing the GPP ${ }_{w} / G P P_{T}$ ratio in the constant-depth series, significant differences were evident in autumn ( $\mathrm{p}_{1}$ and $\left.\mathrm{p}_{2} \leq 0.05\right)$ experiment (Fig. 8b), but not in the summer (Fig. 8a). The same pattern seen for the $\mathrm{chl}_{\mathrm{W}} / \mathrm{chl}_{T}$ ratio was also observed in the GPP ${ }_{W}$ $G P_{T}$ ratio in this series. That is, the $\mathrm{GPP}_{W} / \mathrm{GPP}_{\mathrm{T}}$ ratio was highest in the A tanks, intermediate in the $C$ tanks, and lowest in the E tanks (Fig. 8a). Although the $\mathrm{chl}_{\mathrm{W}} / \mathrm{chl}_{\mathrm{T}}$ ratio was higher

Three weeks into the experiments, the ratio $\mathrm{chl}_{\mathrm{w}}$ ' $\mathrm{chl}_{\mathrm{T}}$ was greater than 0.5 in all but the widest mesocosms (i.e. the $\mathrm{E}$ tanks) in both seasons (Fig. 7). This pattern held true in spite of the large difference in periphyton biomass in these 2 seasonal experiments (Fig. 2). Comparing this ratio within the constant-depth series, significant treatment effects were detected among mesocosms in the summer $\left(p_{1}<0.01\right)$, although no significant differences were found for time $x$ treatment. In the autumn experiment, treatment effects were less pronounced $\left(\mathrm{p}_{1}=0.08\right)$. The $\mathrm{chl}_{\mathrm{W}} / \mathrm{chl}_{\mathrm{T}}$ ratio was negatively related to mesocosm radius, with values generally highest in the $\mathrm{A}$ tanks, intermediate in the $C$ tanks, and lowest in the $\mathrm{E}$ tanks (Fig. 7a, b). in the $\mathrm{C}$ than the $\mathrm{A}$ tanks for a short period (between the $3 \mathrm{rd}$ and 4 th $w \mathrm{k}$ ) in the autumn experiment, the mean value of $\mathrm{GPP}_{W} / \mathrm{GPP}_{\Upsilon}$ was significantly higher for A tanks than for $\mathrm{C}$ tanks. The GPP $/$ /GPP ratio of the $\mathrm{D}$ tanks was significantly higher than that in both the $B$ and $C$ tanks ( $p_{1}$ and $p_{2}<0.05$ ) in the constant-shape series during the summer (Fig. $8 \mathrm{c}$ ), despite the fact that no significant difference was observed for the $\mathrm{chl}_{\mathrm{W}} / \mathrm{ch}_{\mathrm{T}}$ ratio. This ratio was not significantly different in this series in the autumn experiment. There are 3 instances where the ratio of $\mathrm{GPP}_{W} / \mathrm{GPP}_{\Upsilon}$ exceeded 1.0 (Fig. $8 \mathrm{~b}, \mathrm{c}$ ). While this is impossible from a theoretical perspective, it is possible given our operational definition (GPP = $N P P+R$ ) and the significance will be discussed below.
Fig. 6. Linear relationships between intensity of phytoplankton-periphyton interactions in pre-nutrient-addition periods (i.e. same coefficients as shown in Table 3) and ratio of wall area to water volume $\left(A_{w} / V\right)$ for summer $(0$, solid lines) and autumn ( dashed lines) experiments. See Table 3 for details. 'Signuficant at $p<0.05$
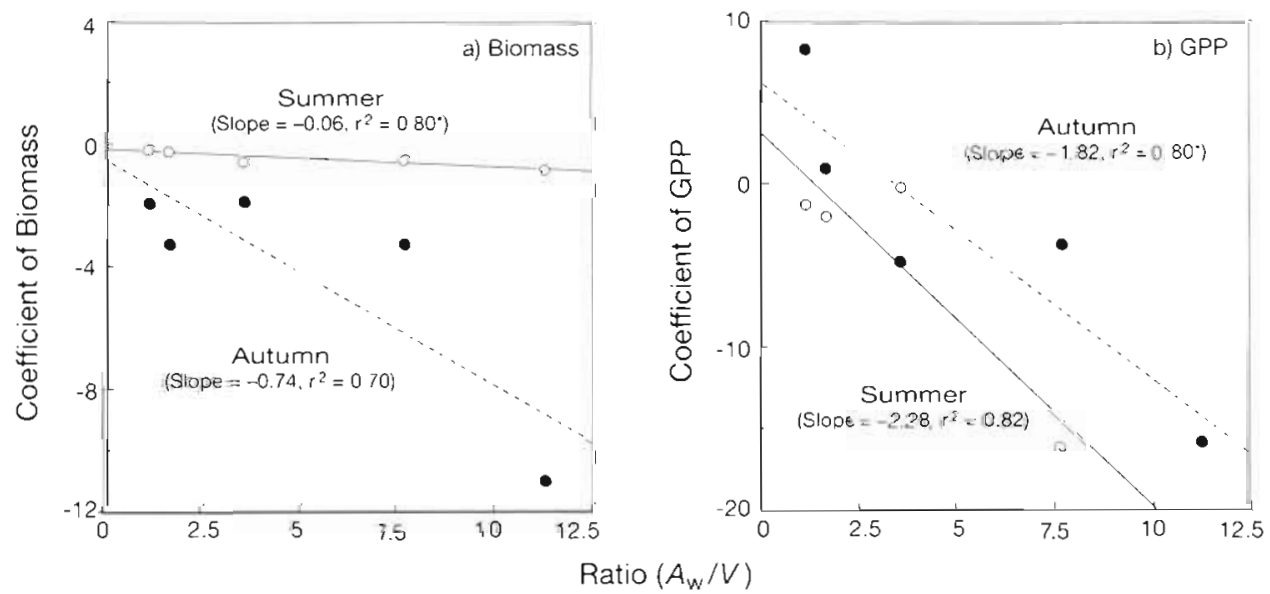


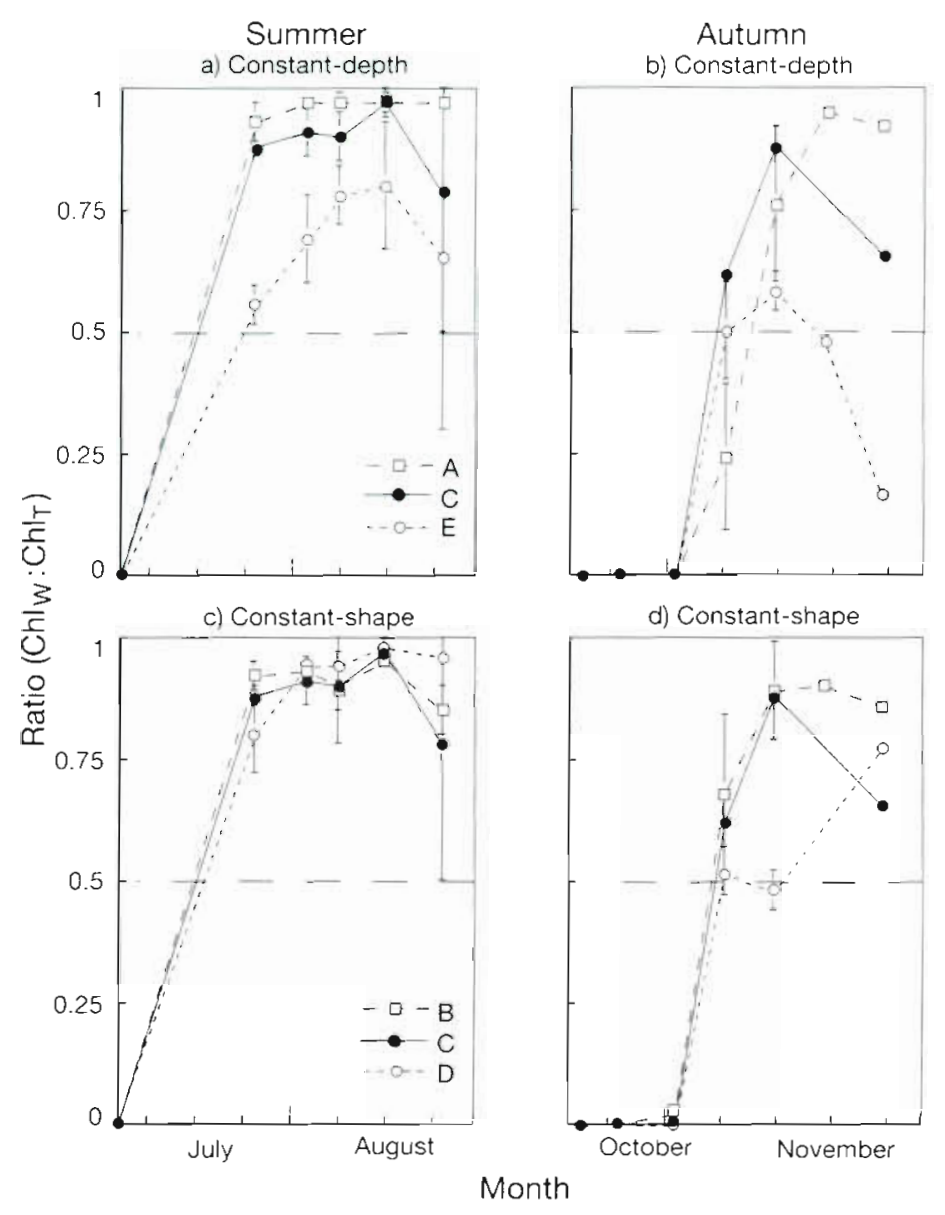

Fig. 7. Ratios of periphyton chl a $\left(\mathrm{chl}_{w}\right)$ to combined $\mathrm{chl}$ a $\left(\mathrm{chl}_{\mathrm{T}}=\right.$ periphyton + phytoplankton) in constant-depth and constant-shape series in summer and autumn experiments. Labels shown in a and $\mathrm{c}$ also apply to $b$ and $d$, respectively. Horizontal dashed lines indicate a ratio of 0.5 development of periphytic wall communities (Eppley et al. 1978, Dudzik et al. 1979, Rees 1979, Grollé \& Kuiper 1980, Kuiper et al. 1983. Kuiper 1984, Lundgren 1985). The duration and magnitude of the phytoplankton bloom peak might cause nutrient depletion and lightshading effects, thus delaying the development of the periphytic community. Indeed, this sequencing of phytoplankton blooms followed by periphyton development occurred in all of our experimental systens (Table 3, Fig. 6). Periphyton biomass eventually declined as material sloughed off the walls of the tanks towards the end of both experiments (Fig. 2). While general senescence may have been a factor, this periphyton sloughing appeared to be caused by the trapping of gas bubbles between periphyton and the mesocosm walls.

Although an initial exponential growth of periphyton was evident in both seasons of this study, biomass accumulation was 10 -fold higher in summer compared to autumn (Fig. 2). Because temperature and light intensity were controlled in these experimental ecosystems (Table 1), these factors could not have been responsible for this large seasonal difference. Higher grazing losses to zooplankton in autumn may have helped prevent accumulation of periphyton biomass (e.g. White \& Roman 1992). Although zooplankton abundance and biomass did not differ significantly between seasons in this study, field studies in Chesapeake Bay suggest strong seasonal variation in grazing rates per animal, with relatively high rates often occurring in late summer and early autumn (Brownlee \& Jacobs 1987, White \& Roman 1992).

\section{DISCUSSION}

\section{Temporal scaling of wall periphyton}

The initial exponential rates of accumulation of wall periphyton biomass appear to be typical of those found for many marine and estuarine mesocosms (Eppley et al. 1978, Grollé \& Kuiper 1980). Comparable experiments with freshwater mesocosm, however, suggest slower rates of periphytic growth (Jassby et al. 1977. Dudzik et al. 1979, Rees 1979).

The rate at which periphytic communities develop on mesocosm walls may also depend on the temporal patterns of phytoplankton communities. Previous studies have reported a general pattern where phytoplankton tend to peak within the first few weeks after mesocosm initiation, with this peak then followed by

\section{Spatial scaling effects on wall periphyton}

Earlier investigators (Jassby et al. 1977, Dudzik et al. 1979, Gamble \& Davies 1982) have hypothesized that effects of wall periphyton on experimental ecosystem dynamics are directly related to the $A_{W} / V$ ratio (2/radius) of mesocosms. Although these studies did not specify how periphyton growth per unit wall area might scale with system $A_{w} / V$ ratio, the implication is that there would be no relationship. This would yield a linear relationship between wall periphyton per unit water volume and $A_{w} / V$ ratio. The results of our study, however, revealed significant negative correlations between $A_{w} / V$ ratio and mean periphyton biomass (per $\mathrm{m}^{2}$ wall area) in both preand post-nutrient-addition periods, and over the course of both summer and autumn experiments (Fig. 5a). 


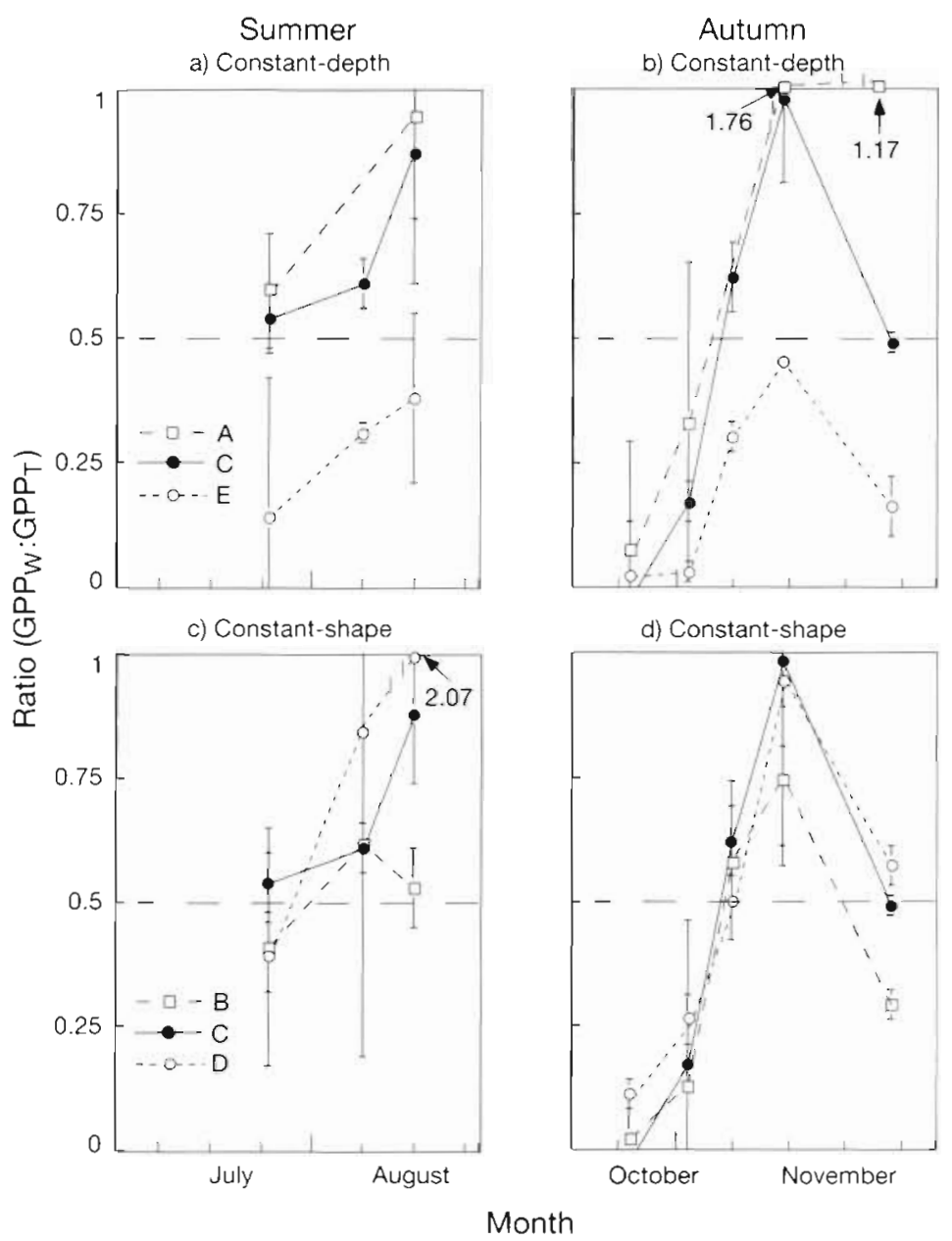

Fig. 8. Ratios of periphyton gross primary production $\left(\mathrm{GPP}_{w}\right)$ to whole experimental ecosystem GPP (GPP.T) in constant-depth and constantshape series in summer and autumn experiments. Labels shown in a and $c$ also apply to $b$ and $d$, respectively. Horizontal dashed lines indicate $a$ ratio of 0.5

The general equation for these relationships can be written as follows:

$$
B_{W A}=B_{0}-K_{C}\left(A_{W} / V\right)
$$

where $B_{W_{A}}$ is biomass of wall periphyton expressed per $\mathrm{m}^{2}$ wall area; $B_{0}$ and $K_{C}$ are the intercept and slope of the linear regression. The biomass of wall periphyton per $\mathrm{m}^{3}$ of water volume, $B_{w v}$, can be expressed by multiplying Eq. (4) by $A_{w} / V$ ratio, which gives the following equation:

$$
B_{W V}=B_{0}\left(A_{W} / V\right)-K_{C}\left(A_{W} / V\right)^{2}
$$

Significant quadratic relationships of this form between periphyton volumetric biomass $\left(\mathrm{m}^{-3}\right)$ and $A_{W} / V$ ratio (with $K_{C}$ prescribed as the coefficient of the quadratic term) were evident in both summer and autumn experiments (Fig. 5c). Analogous relationships (Eqs. 4
\& 5) were also observed between periphyton GPP and $A_{W} / V$ ratio for both experiments (Fig. $5 b$, d).

There are various alternative ways that these scaling relations (Eqs, 4 \& 5) could have been formulated. For example, one could start with a linear regression of periphyton biomass per water volume versus $A_{W} / V$, and then use this to derive other linear relationships for biomass per unit wall area versus $V / A_{W}$. Alternatively, mesocosm radius ( $r$ ), rather than $A_{W} / V$, could be assigned as the independent variable, in which case the regression for periphyton $\left(\mathrm{m}^{-2}\right)$ versus $r$ would take a hyperbolic form, with a negative quadratic for the regression of periphyton $\left(\mathrm{m}^{-3}\right)$ versus $r$ The important point here is not the exact form of these relations, but rather the fact that, in contrast to the speculations of previous investigators, our study indicates that biomass and GPP per unit wall area are significantly related to tank radius.

It appears that water column depth was also an important physical scaling variable controlling periphytic wall growth in our mesocosms. Multiple linear regression analyses of mean periphyton biomass $\left(\mathrm{m}^{-2}\right)$ versus 2 variables ( $A_{W} / V$ and depth) yielded somewhat equivocal results, with significant depth effects in summer but not autumn experiments. In comparisons of deep and shallow tank types of the same volume, there was a consistent pattern in the summer, with wall periphyton biomass and GPP higher for deeper tanks than was predicted from the radius regression (Fig. 5a, b). The pattern was, however, ambiguous in the autumn. At this point it is difficult to speculate as to mechanisms whereby water depth exerts a scaling effect on wall periphyton. One possible explanation is that in relatively deep systems, periphytic algal cells are able to photo-adapt to the essentially constant light regimes they experience at fixed depth, whereas phytoplankton are light limited as they mix through the water column (e.g. Lewis et al. 1984).

\section{Factors regulating periphytic growth}

In our study, both biomass (Fig. 5a) and production (Fig. 5b) of periphyton communities expressed per unit wall area were negatively related to the $A_{W} / V$ ratio (or positively related to radius of experimental ecosystems. Here, we consider factors that may have been 
important in regulating periphyton biomass and growth to produce these scaling relations.

Although all mesocosm communities received similar surface light intensity in both seasons (Table 1), $k_{\text {id }}$ increased significantly with decreasing radius due to absorbance by container walls (Petersen et al. 1997, Kemp unpubl. data). This implies that the light available for periphyton growth increased with increasing mesocosm radius. Indeed, a significant negative relationship was found between periphyton biomass $\left(\mathrm{m}^{-2}\right)$ and $k_{d}$ (Table 2) A previous study (Rees 1979) found qualitatively more periphyton growth on the top than the bottom of mesocosm walls suggesting the potential importance of light limitation. In our study, however we found no significant vertical decline in periphyton biomass. If anything, data on vertical distribution of wall periphyton suggested peak biomass at or below mid-depth. These vertical distributions of periphyton biomass may thus indicate regulation by factors in addition light

Three factors suggest that periphyton in our systems were indeed nutrient limited. First, a positive relationship was observed between periphyton biomass (per unit wall area) and mean nutrient concentrations (Table 2). Second, exponential growth of periphyton was observed immediately after nutrient addition (Fig 2). A similar enhancement of wall growth after nutrient addition has also been observed in in situ lake mesocosm studies (Blumenshine et al. 1997, Lodge et al. 1997). Third, the C/N atomic ratios of periphyton, which were relatively high before nutrient addition, approached Redfield proportions (6.6) immediately after nutrient addition, and then increased again as dissolved inorganic nutrient concentrations declined in both seasons (Table 4). This pattern implies nitrogen limitation

It has been suggested that under nutrient-limited conditions, nutrient uptake by periphyton on side walls should be inversely related to enclosure radius (Dudzik et al. 1979). The logic behind this thinking is that periphyton in narrow systems (i.e. systems with a high $A_{w} / V$ ratio) essentially have a smaller total pool of water column nutrients to use than do periphyton occupying wide tanks (with low $A_{W} / V$ ratios) The negative linear relationship observed between periphyton biomass per unit wall area and $A_{W} / V$ ratio (Fig 5a) is consistent with these dimensional arguments for mutrient limitation

In addition to light and nutrients, accumulation of periphytic biomass may also have been regulated by losses to herbivorous grazers. The dominant zooplankter in our experiments was the copepod Acartia tonsa, with no other herbivores of significant abundance. Although these calanoid copepods are generally thought to consume primarily planktonic algae, anecdotal observations document their ability to feed on attached algae as well (Conover et al. 1986). In general, zooplankton abundances in our experimental systems were higher than typical values reported for Chesapeake Bay (Brownlee \& Jacobs 1987), indicating considerable potential for grazing effects. Zooplankton have been observed to aggregate near mesocosm walls in this and in previous studies (Stephenson et al. 1984), suggesting potential grazing on attached periphyton. Furthermore, periphytic biomass $\left(\mathrm{m}^{-2}\right)$ was negatively related to zooplankton abundance (Table 2), suggesting zooplankton grazing pressure may have decreased with increasing tank radius. Because this relationship is also consistent with light and nutrient effects on periphytic growth, we are left to conclude that light, nutrient, and grazing pressure may all have played significant roles in controlling the accumulation of periphyton biomass $\left(\mathrm{m}^{-2}\right)$ on mesocosm walls.

\section{Wall periphyton effects on ecosystem processes}

Mesocosms are widely recognized as valuable research tools in aquatic ecology (e.g Menzel 1990, Takahashi 1990, Crossland \& La Point 1992); however, previous authors have suggested that periphyton growth on container walls may seriously reduce experimental realism and confound extrapolation of results

Table 4. Ratio of carbon to nitrogen (C/N, atomic weight) of wall periphyton in different periods of summer and autumn experments. Nutrient additions were started on 8 August and 7 November 1994 in summer and autumn experiments, respectively. Values are mean $\pm \mathrm{SE} ; \mathrm{n}=3$ replicated mesocosms

\begin{tabular}{|c|c|c|c|c|c|c|}
\hline \multirow{2}{*}{ Tank } & \multicolumn{3}{|c|}{ Summer experiment } & \multicolumn{3}{|c|}{ Autumn experiment } \\
\hline & Aug 4 & Aug 16 & Aug 25 & Nov 9 & Nov 16 & Dec 1 \\
\hline A & $17.5 \pm 0.5$ & $10.4 \pm 0.4$ & $11.9 \pm 0.3$ & $7.1 \pm 0.1$ & $11.8 \pm 1.4$ & $14.4 \pm 1.4$ \\
\hline B & $12.4 \pm 0.5$ & $10.9 \pm 0.8$ & $11.7 \pm 0.6$ & $7.8 \pm 0.3$ & $14.5 \pm 1.2$ & $13.6 \pm 0.8$ \\
\hline C & $9.4 \pm 0.4$ & $8.6 \pm 0.5$ & $12.8 \pm 0.5$ & $6.9 \pm 0.2$ & $12.3 \pm 1.2$ & $12.4 \pm 1.2$ \\
\hline D & $12.6 \pm 0.6$ & $7.2 \pm 0.1$ & $7.0 \pm 0.3$ & $6.5 \pm 0.2$ & $8.5 \pm 0.4$ & $13.3 \pm 0.3$ \\
\hline$E$ & $11.6 \pm 0.6$ & $8.7 \pm 0.5$ & $10.1 \pm 0.3$ & $6.9 \pm 0.3$ & $10.8 \pm 0.7$ & $10.3 \pm 0.3$ \\
\hline
\end{tabular}


to natural ecosystems (Dudzik et al. 1979, Harte et al. 1980, Lodge et al. 1997). Our results indicate that wall periphyton can dominate experimental ecosystems in both autotrophic biomass (e.g. Fig. 7) and primary production (e.g. Fig. 8) within weeks after experiments begin. In our experiments, the relative effect of periphyton on biomass and production tended to decline with tank radius, as indicated by the fact that mean $\mathrm{GPP}_{W} / \mathrm{GPP}_{\mathrm{T}}$ in the constant-depth series was also positively related to the $A_{W} / V$ ratio, $\left(r^{2}=0.65\right.$ and 0.97 in summer and autumn, respectively). Thus, it is clear that wall periphyton effects can be minimized with short-term studies conducted in wide experimental systems.

In the results section we pointed out 3 instances in which the ratio of $\mathrm{GPP}_{\mathrm{W}} / \mathrm{GPP}_{\mathrm{T}}$ exceeded 1.0 (Fig. 8b, c). These discrepancies may be attributable to experimental error. It is also possible, however, that these numbers are accurate and reflect important effects of wall periphyton on ecosystem processes. For this ratio to exceed 1.0 the sum of the gross photosynthesis of the water column and benthos (i.e. the other constituents of $\mathrm{GPP}_{\mathrm{T}}$ ) must be negative. Although a negative gross photosynthesis is impossible from a theoretical perspective, a negative value for the operationally defined variable, GPP, is feasible. This is because we have followed the standard convention of defining GPP operationally as the sum of the daytime increase in oxygen (NPP) and the nighttime decrease in oxygen (R). With this operational definition, GPP can be negative if NPP is negative and has a larger magnitude than night time $R$. This can occur if $R$ during the day exceeds the sum of nighttime $R$ and the production of oxygen resulting from photosynthesis. This situation is plausible in a system that has consumers that exhibit large diel variation in respiration following day/night fluctuation in availability of labile photosynthate (e.g Sampou \& Kemp 1994). In principle, $\mathrm{GPP}_{W} / \mathrm{GPP}_{T}$ can exceed 1.0 if the water column and sediment communities are net heterotrophic and dominated by organisms that actively consume and respire exudates from wall periphyton and/or phytoplankton during the daytime when photosynthesis is occurring. At any rate, it is clear that these very high ratios of wall production relative to total production indicate that periphytic communities eventually dominate the ecology of these systems.

Even though the relative contributions of periphyton decreased significantly with increasing radius, total ecosystem GPP did not generally vary among mesocosms with the same depth but different widths (Petersen et al. 1997). A competitive balance between groups of autotrophs in which increases in one group are accompanied by decreases of similar magnitude in another has been demonstrated ie.g. Lewis \& Platt 1982). Evidence for compensatory interactions of this sort in our mesocosms include the negative correlations between wall periphyton and phytoplankton (Fig. 6). Further evidence includes the fact that the increase in volumetric biomass and production of wall periphyton $\left(\mathrm{m}^{-3}\right)$ with increasing $A_{W} / V$ ratio was accompanied by decreases in biomass and production of phytoplankton (Figs, 5c, d \& 6).

The scaling relations observed here for wall periphyton and other properties of experimental ecosystems are indicative of a number of important interactions. Because periphytic biomass per unit wall area was related to mesocosm $A_{W} / V$ ratio, it might be anticipated that nutrient uptake by wall periphyton would also scale to the radius of experimental ecosystems. As nutrient uptake by wall periphyton increased with the $A_{W} / V$ ratio, nutrient concentrations in mesocosm water would decrease. This was, in fact, the case in our study where nutrient concentration were negatively correlated with periphyton volumetric biomass (Table 2). Furthermore, zooplankton abundance was directly proportional to periphyton biomass $\left(\mathrm{m}^{-3}\right)$ in both seasons (Table 2). The significant negative and positive correlations between zooplankton abundance and periphyton biomass, per $\mathrm{m}^{2}$ wall area and per $\mathrm{m}^{3}$ water volume, respectively, leave open the possibility of both top-down regulation of periphyton by zooplankton and bottom-up regulation of zooplankton by periphyton.

Although periphyton communities growing on mesocosm walls are undesirable artifacts in most experiments, in certain circumstances they might be considered analogous to communities growing on hard substrates in natural aquatic ecosystems (Confer 1972 , Blumenshine et al. 1997). Periphytic wall communities are, in some senses, similar to those in littoral habitats growing on rocks, pilings, and vascular plant leaves. These communities should be distinguished from those on sediments (epipelic algae) because of their reduced tendency to accumulate sinking particulate organic matter (Blumenshine et al. 1997); consequently, they tend to be more autotrophic, more nutrient limited, and less light limited than sediment littoral communities. It is not surprising, then, that the wall periphyton in our experimental systems responded more rapidly to pulsed nutrient additions than did phytoplankton or sediment microalgae. Thus, the partitioning of biomass between periphyton and other autotrophic groups may provide an index of trophic conditions in mesocosm studies.

In summary, our study has demonstrated that, without wall cleaning, autotrophic biomass and production of experimental coastal ecosystems can be dominated by periphytic growth within 2 to 4 wk. Although increasing the width (decreasing the $A_{w} / V$ ratio) of mesocosms can reduce the effect of periphyton, wallgrowth dominance of ecosystem processes was ob- 
served within weeks for even relatively wide experimental systems (i.e. E tanks, with diameter $=3.6 \mathrm{~m}$ and $A_{w} / V$ ratio $\left.=1.1 \mathrm{~m}^{-1}\right)$. Growth of wall periphyton per $\mathrm{m}^{2}$ wall area in these experiments scaled positively with tank radius (negatively with $A_{w} / V$ ratio) Our results also suggest a secondary scaling effect, whereby wall growth may tend to increase with mesocosm depth, although mechanisms for this effect are unclear Indirect evidence indicates that nutrients, light and zooplankton grazing may all have contributed to regulating periphyton growth. Conversely, our results strongly suggest that ecosystem production, nutrient uptake and abundances of phytoplankton and zooplankton assemblages were all significantly influenced by growth of wall periphyton. These findings imply that dimensional scaling of wall periphyton needs to be considered for comparisons among experiments and between experiments and nature.

Acknowledgements. This work was supported by a grant from the U.S. Environmental Protection Agency as part of the Multiscale Experiment Ecosystem Research Center (MEERC) at the University of Maryland Center for Environmental Science (Grant no. R819640). The work of J.E.P. was performed while the recipient of a grant from the Graduate Fellowships for Global Change Program administered by Oak Ridge Associated Universities for the U.S. Department of Energy, Office of Health and Environmental Research, Atmospheric and $\mathrm{Cl}_{1}$ mate Research Division. We are indebted to Jeff Cornwell Jennifer Gormer, Tim Goertemıller, Debbie Hinkle, Chris Madden and Tom Wazniak, who provided assistance with sampling and analyses as well as valuable discussions durng the course of this research. We thank Mike Roman and Ann Gauzens for allowing us to use their unpublished zooplankton data and Elgin Perry for his statistical advise. Thanks also go to $V_{1 C}$ Kennedy and 3 anonymous reviewers for valuable comments and suggestions on earlier versions of this manuscript.

\section{LITERATURE CITED}

Beyers RJ, Odum HT (1993) Ecological microcosms. SpringerVerlag, New York

Blumenshine SC, Vadeboncoeur Y. Lodge DM, Cottingham KL, Knight SE (1997) Benthic-pelagic links: responses of benthos to water-column nutnent enrichment. J North Am Benthol Soc 16:466-479

Brownlee DC, Jacobs F (1987) Mesozooplankton and microzooplankton in the Chesapeake Bay. In. Majumdar SK, Hall LW, Ausun HM (eds) Contaminant problems and management of living Chesapeake Bay resources. The Pennsylvania Academy of Science, Philadelphia, p 217-269

Carpenter SR, Chisholm SW, Krebs CJ, Schindler DW, Wright RF (1.995) Ecosystem experiments. Science 269:324-327

Carritt DE, Carpenter JH (1966) Comparison and evaluation of currently employed modifications of the Winkler method for determining dissolved oxygen in seawater, a nasco report. $J$ Mar Res 24:286-318

Confer JL (1972) Interrelations among plankton, attached algae, and the phosphorus cycle in artificial open systems. Ecol Monogr 42:1-23

Conover RJ, Herman AW, Prinsenberg SJ, Harris LR (1986) Distribution of and feeding by the copepod Pseudocalanus un- der fast ice during the Arctic spring. Science 232:1245-1247 Crosslend NO, La Point TW (1992) The design of mesocosm experiments. Environ Toxicol Chem 11:1-4

Crowder MJ, Hand DJ (1990) Analysis of repeated measures. Chapman and Hall, Londion

Dudzik M, Harte J, Jassby A, Lapan E, Levy D, Rees J (1979) Some considerations in the design of aquatic microcosms for plankton research. Int J Environ Stud 13:125-130

Eppley RW, Koeller P, Wallace GT (1978) Stirring influences the phytoplankton species composition within enclosed columns of coastal sea water J Exp Mar Biol Ecol 32: $219-239$

Gamble JC, Davies JM (1982) Application of enclosures to the study of marine pelagic systems. In: Grice D, Reeve MR (eds) Marine mesocosms. Springer-Verlag, New York, p 25-48

Gearing JN (1989) The role of aquatic microcosms in ecotoxlcological research as illustrated by large marine systems. In: Levin SA, Harwell MA, Kelly JR, Kimball KK (eds) Ecotoxicology: problems and approaches. Springer-Verlag. New York, p 411-470

Giesy JP (ed) (1980) Microcosms in ecological research. DOE Symposium Series 52, Conf-781101, Nat Tech Inform Srr, Springfield, VA

Grice D, Reeve MR (eds) (1982) Marine mesocosms. SpringerVerlag, New York

Grollé T, Kuiper J (1980) Development of marine periphyton under mercury stress in a controlled ecosystem experiment. Bull Environ Contam Toxicol 24:858-865

Harte J, Levy D, Rees J, Saegebarth E (1980) Making microcosms an effective assessment tool. In: Giesy JP (ed) Microcosms in ecological research. DOE Symposium Series 52, Conf-781101, Nat Tech Inform Serv, Springfield, VA, $p 105-137$

Jassby A, Dudzık M, Rees J, Lapan E, Levy D, Harte J (1977) Production cycles in aquatic microcosms. Rep no. EPA600/7-77-097. Environ Prot Agency, Washington, DC

Kelly JR, Berounsky VM, Nixon SW, Oviatt CA (1985) Benthicpelagic coupling and nutrient cycling across an experimental eutrophication gradient. Mar Ecol Prog Ser 26. $207-219$

Kemp WM, Lewis MR, Cunningham JJ, Stevenson JC, Boynton WR (1980) Microcosms, macrophytes, and hierarchies: environmental research in the Chesapeake Bay. In: Giesy JP (ed) Microcosms in ecological research. DOE Symposium Series 52, Conf-781101. Nat Tech Inform Serv, Springfield, VA, p $911-936$

Kuper $J$ (1981) Fate and effects of mercury in marine plankton communities in experimental enclosures. Ecotoxicol Environ Saf 5:106-134

Kuiper J (1984) Marme ecotoxicological test: multispecies and model ecosystem experıments. In: Persoone $G$, Jaspers $E$, Claus C (eds) Ecotoxicological testing for the marine environment. State Univ Ghent and Inst Mar Sci Res, Bredene, Belgium, p 527-588

Kuiper J, Brockmann UH, van het Groenewoud H, Hoornsman G, Hammer KD (1983) Influences of bag dimensions on the development of enclosed plankton communities during POSER. Mar Ecol Prog Ser 14:9-17

Kuuppo-Leinıkki P. Autio R. Hällfors S, Kuosa H, Kuparinen J. Pajuniemi R (1994) Trophic interactions and carbon flow between picoplankton and protozoa in pelagic enclosures manipulated with nutrients and a top predator. Mar Ecol Prog Ser 107:89-102

Lallı CM (1990) Enclosed expermental manne ecosystems: a review and recommendations. Spnnger-Verlag, New York

Lewis MR, Cullen JJ, Platt T (1984) Relationships between vertıcal mixing and photoadaptation of phytoplankton: 
similarity criteria. Mar Ecol Prog Ser 15:141-149

Lewis MR, Platt T (1982) Scales of variability in estuarine ecosystems. In: Kennedy VS (ed) Estuarine comparisons. Academic Press, New York, p 3-20

Lodge DM, Blumenshine SC, Vadeboncoeur Y (1997) Insights and applications of large-scale, long-term ecological observations and experiments. In: Resetarits WJ, Bernardo J (eds) The state of experimental ecology: questions, levels and approaches. Oxford University Press, New York (ın press)

Lundgren A (1985) Model ecosystems as a tool in freshwater and marine research. Arch Hydrobiol Suppl 70:157-196

Menzel D (1990) Preface. In: Lall CM (ed) Enclosed experimental marine ecosystems: a review and recommendations. Springer-Verlag, New York, p v-vi

Odum EP (1984) The mesocosm. BioSci 34:558-562

Odum HT (1956) Primary production in flowing water. Limnol Oceanogr 1:102-117

Oviatt C, Doering P, Nowicki B, Reed L, Cole J, Frithsen J (1995) An ecosystem level experiment on nutrient limitation in temperate coastal marine environments. Mar Ecol Prog Ser 116:171-179

Parsons TR, Maita Y, Lalli CM (1984) A manual of chemical and biological methods for seawater analysis. Pergamon Press, New York

Perez KT, Morrison GE, Davey EW, Lackie NF, Soper AE, Blasco RJ, Winslow DL (1991) Influence of size on fate and ecological effects of kepone in physical models. Ecol Appl $1: 237-248$

This article was presented by Jennifer Purcell (Senior Editorial Advisor), Cambridge, Maryland, USA
Petersen JE, Chen CC, Kemp WM (1997) Scaling aquatic primary productivity: experiments under nutrient and light limited conditions. Ecology 78:in press

Rees JT (1979) Community development in freshwater microcosms. Hydrobiologia 63:113-128

Sampou P, Kemp WM (1994) Factors regulating plankton community respiration in Chesapeake Bay. Mar Ecol Prog Ser 110:249-258

Stephenson GL, Hamilton P, Kaushik NK, Robinson JB, Solomon KR (1984) Spatial distribution of plankton in enclosures of three sizes. Can J Fish Aquat Sci 41:1048-1054

Takahashi M (1990) Pelagic mesocosms: 1. Food chain analysis. In: Lalli CM (ed) Enclosed expermental marine ecosystems: a review and recommendations. SpringerVerlag, New York, p 61-80

Threlkeld ST, Drenner RW (1987) An expenmental mesocosm study of residual and contemporary effects of an omnivorous filter-feeding, clupeid fish on plankton community structure. Limnol Oceanogr 32:1331-1341

Van Heukelem L, Lewitus AJ, Kana TM, Craft NE (1994) Improved separations of phytoplankton pigments using temperature-controlled high performance liquid chromatography. Mar Ecol Prog Ser 114:303-313

White JR, Roman MR (1992) Seasonal study of grazing by metazoan zooplankton in the mesohaline Chesapeake Bay. Mar Ecol Prog Ser 86:251-261

Whitney DE, Darley WM (1979) A method for the determination of chlorophyll $a$ in samples containing degradation products. Limnol Oceanogr 24:183-186

Manuscript recelved: July 22, 1996

Revised version accepted: June 12, 1997 